\title{
KETAHANAN SERANGAN PENYAKIT KARAT TUMOR \\ PADA UJI KETURUNAAN SENGON (Falcataria moluccana) \\ DI BONDOWOSO, JAWA TIMUR
}

Gall Rust Disease Defense Attacks at Progeny Test of Falcataria moluccana

in Bondowoso, East Java

\author{
Dedi Setiadi, Mudji Susanto dan Liliana Baskorowati \\ Balai Besar Penelitian Bioteknologi dan Pemuliaan Tanaman Hutan \\ Jl. Palagan Tentara Pelajar Km 15, Purwobinangun, Pakem, Sleman, Yogyakarta 55582 \\ e-mail: Setiadi2009@yahoo.com
}

\begin{abstract}
As a part of tree improvement project of sengon (Falcataria moluccana L. Nielsen) several progeny test were established in December 2011. One of those progeny test was established in Bondowoso, East Java. Row Column Desgin (Incomplete Block Design) was used as experimental design involving 70 families (9 Papua provenance and 1 provenance Solomon), 4 replications (blocks), 4 trees per plot and a spacing of $3 \times 2 \mathrm{~m}$. Observations were made at the age of 6 and 12 months, including recorded the percent of survival plants, height, diameter and the gall rust incidence. Results showed that in general, the early growth of individual plant in this plot demonstrated a fairly good performance with the survival rate of $98.5 \%$ (6 months old), and 96.9\% (1 year old). The early growth of sengon varied significantly between provenances. The best growth demonstrated by provenances from Meagama, Holima and Hobikosi. Early estimation of individual heritability of plant height categorised in low $\left(h^{2}{ }_{i}=\right.$ 0.07 to $0.11, h_{f}^{2}=0.16$ to 0.21$)$, whereas individual heritability of diameter were catagorised in medium $\left(h^{2}{ }_{i}=0,08\right.$ to $0.27, h_{f}{ }_{f}=0.15$ to 0.43$)$. Moreover, the positive value of the genetic correlation revealed between height and diameter (0.88 and 0.85). Several individual trees originated from Holima, Meagama and Elagaima exhibited $0 \%$ of gall rust disease incidence.
\end{abstract}

Keywords: Falcataria moluccana, heritability, genetic correlations, provenances, gall rust

\begin{abstract}
ABSTRAK
Beberapa uji keturunan sengon (Falcataria moluccana L. Nielsen) dibangun pada bulan Desember 2011, sebagai bagian dari kegiatan pemuliaan tanaman jenis tersebut. Salah satu uji keturunan yang dibangun berlokasi di Bondowoso, Jawa Timur. Dibangun dengan menggunakan Rancangan Baris Kolom (Incomplete Block Design) terdiri dari 70 famili (9 provenans asal Papua dan 1 provenans asal Solomon), 4 ulangan, 4 pohon per plot (tree plot) dan jarak tanam $3 \times 2 \mathrm{~m}$. Pengamatan dilakukan pada umur 6 dan 12 bulan terhadap persen hidup tanaman, tinggi, diameter dan ketahanan terhadap serangan karat tumor. Hasil penelitian menunjukkan bahwa secara umum pertumbuhan tanaman cukup baik dengan persen hidup umur 6 bulan sebesar 98,5\%, umur 12 bulan sebesar 96,9\%. Pertumbuhan tanaman bervariasi antar provenans, dimana tiga provenans dengan pertumbuhan terbaik ditunjukkan oleh provenans Meagama, Holima dan Hobikosi. Nilai heritabilitas individu dan famili untuk sifat tinggi tanaman sengon umur 6 dan 12 bulan termasuk katago-
\end{abstract}


ri rendah $\left(\mathrm{h}^{2}=0,07-0,08, \mathrm{~h}_{\mathrm{f}}^{2}=0,16-0,15\right)$, sedangkan untuk sifat diameter termasuk katagori sedang, rendah sampai sedang $\left(h^{2}=0,11-0,27, h_{f}^{2}=0,21-0,43\right)$. Korelasi genetik antara tinggi dan diameter menunjukkan nilai positif dan cukup tinggi $(0,88$ dan 0,85$)$. Pohon-pohon yang berasal dari provenans Holima, Meagama dan Elagaima tidak menunjukkan adanya penyakit karat tumor, dimana persentase luas serangan dan intensitas serangannya $0 \%$.

\section{Kata kunci: Falcataria moluccana, heritabilitas, korelasi genetik, provenans, karat tumor}

\section{PENDAHULUAN}

\section{A. Latar Belakang}

Sengon (Falcataria moluccana Miq sinonim Paraserientes falcataria (L.) Nielsen, Albazia falcataria (L.) Fosb) merupakan salah satu spesies yang cukup luas dikembangkan untuk hutan tanaman industri dan hutan kemasyarakatan di Jawa dan di luar Jawa (Atmosuseno, 1998 dalam Siregar, U.J. dan Saimima, P.A., 2011). Jenis ini dipilih karena mempunyai daur pertumbuhan pendek, mampu beradaptasi pada berbagai jenis tanah. Kayu jenis ini dapat digunakan sebagai bahan furniture kelas menengah, kayu pertukangan ringan, kayu peti kemas dan sebagai bahan baku pulp, kertas dan kayu lapis serta veneer, dengan kelas awet IV-V (Martawijaya dkk, 1992). Peningkatan produktivitas hutan tanaman setidaknya memerlukan dua pendekatan, yaitu perbaikan kualitas tempat tumbuh dan penggunaan benih unggul. Oleh karena itu, upaya pengadaan benih bergenetik unggul sangat penting dan harus diprioritaskan (Na'iem 2005). Pemilihan jenis dan provenans merupakan langkah penting yang harus dilalui, karena pertambahan produktivitas hutan dapat dicapai dengan mudah dan biasanya hasilnya lebih baik dibandingkan beberapa siklus kegiatan pemuliaan pohon melalui proses seleksi dan perkawinan yang membutuhkan peralatan, waktu dan pembiayaan yang besar (Turnbull 1996).

Penyakit karat tumor merupakan salah satu penyakit yang berbahaya pada tanaman sengon. di Jawa khususnya di Jawa Timur, penyakit karat tumor pada sengon telah dilaporkan pada tahun 2003. Namun, karena kurangnya perhatian pihak-pihak terkait, tindakan pencegahan terlambat dilakukan, akhirnya pada tahun 2005, penyakit ini telah menyebar luas di seluruh Jawa Timur, terutama di lereng gunung Semeru, pegunungan Ijen, dan gunung Raung, meliputi Banyuwangi, Bondowoso, 
Pasuruan, Malang, Probolinggo dan Jember. Kabupaten Kediri, yang merupakan salah satu sentra pertanaman sengon di Jawa, saat ini juga telah mengalami serangan karat tumor, meskipun masih sporadis (Anggraeni, 2010).

Pengendalian penyakit melalui introduksi sumber genetik baru telah dilakukan oleh Balai Besar Penelitian Bioteknologi dan Pemuliaan Tanaman Hutan Yogyakarta pada tahun 2011, dengan membangun beberapa plot uji keturunan sengon dari provenans Papua dan Solomon di beberapa lokasi, salah satunya di Bondowoso, Jawa Timur. Adapun penelitian ini bertujuan untuk memberikan informasi awal tentang pertumbuhan dan ketahanan terhadap serangan penyakit karat tumor pada plot uji keturunan sengon di Bondowoso.

\section{BAHAN DAN METODE}

\section{A. Waktu dan Tempat Penelitian}

Plot penelitian dibangun pada tahun 2011 pada Kawasan Hutan Dengan Tujuan Khusus (KHDTK) Balai Besar Penelitian Bioteknologi dan Pemuliaan Tanaman Hutan Yogyakarta di Bondowoso. Secara administratif hutan penelitian tersebut terletak di Desa Wringin Anom, Kecamatan
Sukosari, Kabupaten Bondowoso. Tapak uji keturunan memiliki tipe iklim B dengan rerata curah hujan sebesar $2400 \mathrm{~mm} /$ tahun. Musim hujan mulai bulan November sampai dengan April dengan suhu terendah 170C dan suhu tertinggi 300C. Jenis tanahnya bertekstur sedang yang meliputi lempung, lempung berdebu dan lempung liat berpasir. Tapak tergolong datar, terletak pada ketinggian tempat $800 \mathrm{~m}$ di atas permukaan laut. Penelitian dilakukan pada bulan Mei 2011 dan November 2012.

\section{B. Bahan Penelitian}

Bahan penelitian yang digunakan adalah tanaman uji keturunan sengon dari 10 sumber benih yang terdiri dari 9 sumber benih populasi alam Papua dan 1 sumber benih dari Solomon. Data sumber benih dan jumlah famili yang digunakan dalam penelitian ini disajikan pada Tabel 1.

\section{Rancangan Penelitian}

Kebun benih semai uji keturunan sengon ini dirancang mengikuti rancangan baris kolom (Row Colum Design/Incomplte Block Design) yang terdiri atas 70 famili dari 10 provenans dengan 4 ulangan, 4 pohon per plot, jarak tanam $3 \mathrm{~m} \mathrm{x} 2 \mathrm{~m}$. Karakter pertumbuhan yang diukur dalam penelitian ini adalah tinggi pohon dan diameter batang. 
Tabel 1. Sumber asal benih yang digunakan dalam uji keturunan sengon (Falcataria moluccana) di Bondowoso-Jawa Timur

\begin{tabular}{|c|c|c|c|c|c|}
\hline Provenans & $\begin{array}{l}\text { Jumlah } \\
\text { Famili }\end{array}$ & Lokasi & $\begin{array}{l}\text { Grs.Lintang } \\
\text { (Selatan) }\end{array}$ & $\begin{array}{l}\text { Grs. Bujur } \\
\text { (Timur) }\end{array}$ & $\begin{array}{l}\text { Ketinggian } \\
\text { tempat (m dpl) }\end{array}$ \\
\hline Holima & 6 & Wamena (Papua) & $04^{\circ} 03^{\prime} 74.5^{\prime \prime}$ & $138^{\circ} 52^{\prime} 43.9^{\prime \prime}$ & 1669 \\
\hline Meagama & 6 & Wamena (Papua) & $04^{\circ} 36^{\prime} 65.7^{\prime \prime}$ & $138^{\circ} 50^{\prime} 76.3^{\prime \prime}$ & 1711 \\
\hline Elagaima & 6 & Wamena (Papua) & $03^{\circ} 53^{\prime} 92.6^{\prime \prime}$ & $138^{\circ} 49^{\prime} 81.4^{\prime \prime}$ & 1702 \\
\hline Kurulu & 6 & Wamena (Papua) & $03^{\circ} 13^{\prime} 81.7^{\prime \prime}$ & $138^{\circ} 30^{\prime} 83.2^{\prime \prime}$ & 1730 \\
\hline Wadabi & 6 & Serui (Papua) & $01^{0} 52 ’ 16.9 ”$ & $136^{0} 53^{\prime} 46.6^{\prime \prime}$ & 110 \\
\hline Nifasi & 6 & Nabire (Papua) & $03^{\circ} 10^{\prime} 04.5^{\prime \prime}$ & $135^{\circ} 39^{\prime} 07.3 ”$ & 22 \\
\hline Worbag & 6 & Nabire (Papua) & $03^{\circ} 09^{\prime} 13.3^{\prime \prime}$ & $135^{\circ} 41^{\prime} 52.6^{\prime \prime}$ & 25 \\
\hline Maidi & 8 & Nabire (Papua) & $03^{\circ} 10^{\prime} 07.6^{\prime \prime}$ & $135^{\circ} 41^{\prime} 10.5^{\prime \prime}$ & 22 \\
\hline Hobikosi & 5 & Wamena (Papua) & $04^{\circ} 10^{\prime} 45.3^{\prime \prime}$ & $139^{\circ} 10^{\prime} 654^{\prime \prime}$ & 1700 \\
\hline Solomon & 15 & Solomon & - & - & - \\
\hline
\end{tabular}

Diameter batang pada umur 6 bulan diukur pada posisi $15 \mathrm{~cm}$ dari pangkal batang, sedangkan pada waktu umur 12 bulan diukur pada setinggi dada (dbh). Ketahanan serangan penyakit karat tumor diukur menggunakan sistem skor dari 0 sampai 5, dengan kriteria sebagaimana tabel 2.

Intensitas serangan dan luas serangan penyakit karat tumor didasarkan atas kriteria tingkat keparahan serangan (Tabel 3).
Tabel 2. Skor gejala penyakit karat tumor pada tanaman sengon umur $\leq 1$ tahun di lapangan

\begin{tabular}{cl}
\hline Skor & \multicolumn{1}{c}{ Keterangan gejala } \\
\hline 0 & Tanaman sehat, tidak ada gejala \\
1 & $\begin{array}{l}\text { Ada gejala pada pucuk batang dan anak } \\
\text { daun pada pucuk }\end{array}$ \\
2 & Ada gejala pada cabang dan ranting \\
3 & Ada tumor pada cabang dan atau ranting \\
4 & $\begin{array}{l}\text { Ada tumor pada cabang dan atau ranting } \\
\text { serta batang }\end{array}$ \\
5 & $\begin{array}{l}\text { Tanaman kering atau mati karena } \\
\text { penyakit karat tumor }\end{array}$ \\
&
\end{tabular}

Tabel 3. Level tingkat keparahan berdasarkan intensitas serangan dan luas serangan

\begin{tabular}{cccc}
\hline Nilai Luas Serangan & Luas Serangan & Nilai Intensitas Serangan & Tingkat keparahan \\
\hline$<10 \%$ & Jarang & $0 \%$ & Tidak ada \\
$10-<25 \%$ & Kadang-kadang & $<25 \%$ & Rendah \\
$25-<50 \%$ & Biasa & $25-<50 \%$ & Sedang \\
$50-<75 \%$ & Luas & $50-75 \%$ & Parah \\
$>75 \%$ & Sangat luas & $75-100 \%$ & Sangat parah \\
\hline
\end{tabular}




\section{Analisis data}

Data hasil pengukuran dianalisis

untuk mendapatkan informasi keragaman karakter di antara famili-famili yang diuji.

Model anova untuk uji keturunan half-sib dengan rancangan baris dan kolom adalah sebagai berikut :

$$
\mathrm{Y}_{\mathrm{ijklmn}}=\mu+\mathrm{B}_{\mathrm{i}}+\mathrm{R}(\mathrm{B})_{\mathrm{ij}}+\mathrm{C}(\mathrm{B})_{\mathrm{ik}}+\mathrm{P}_{1}+\mathrm{F}(\mathrm{P})_{\mathrm{lm}}+\left(\mathrm{BF} *(\mathrm{P})_{\mathrm{mn}}\right)+\varepsilon_{\mathrm{ijklmn}}
$$

Keterangan:

$\begin{aligned} \mathrm{Y}_{\mathrm{ijklmn}}= & \text { adalah rata-rata plot famili ke-m } \\ & \text { dalam provenans ke-1 pada } \\ & \text { kolom ke-k baris ke-j dalam } \\ & \text { ulangan ke-i provenans ke-j dari } \\ & \text { famili ke-k dalam ulangan ke-i } \\ = & \text { nilai rerata umum } \\ = & \text { pengaruh ulangan ke- } \mathrm{i} \\ \mu & \text { pengaruh baris ke- i yang } \\ \mathrm{B}_{\mathrm{i}} & \text { bersarang dalam ulangan ke-j } \\ \mathrm{R}(\mathrm{B})_{\mathrm{ij}}= & \text { pengaruh kolom ke-i yang } \\ \mathrm{C}(\mathrm{B})_{\mathrm{ik}}= & \text { bersarang dalam ulangan kei-k } \\ \mathrm{P}_{1}= & \text { pengaruh provenans ke-1 } \\ \mathrm{F}(\mathrm{P})_{\mathrm{lm}}= & \text { pengaruh famili ke-1 yang } \\ & \text { bersarang dalam provenans ke-m } \\ \mathrm{BF}(\mathrm{P})_{\mathrm{mn}}= & \text { pengaruh interaksi ulangan ke-m } \\ & \text { pada famili ke-n } \\ \varepsilon_{\mathrm{ijk} l m n}= & \text { eror random. }\end{aligned}$

Heritabilitas famili dan individu setiap sifat yang dihitung menggunakan rumus sebagai berikut (Zobel dan Talbert, 1984):

$$
\begin{aligned}
\mathrm{h}_{\mathrm{f}}^{2} & =\frac{\sigma_{\mathrm{f}}^{2}}{\sigma_{\mathrm{f}}^{2}+\left(\sigma_{\mathrm{bf}}^{2}\right) / \mathrm{b}+\left(\sigma_{\mathrm{e}}^{2}\right) / \mathrm{nb}} \\
\mathrm{h}_{\mathrm{i}}^{2} & =\frac{3 \sigma_{\mathrm{f}}^{2}}{\sigma_{\mathrm{f}}^{2}+\sigma^{2} b_{\mathrm{f}}+\sigma_{\mathrm{e}}^{2}}
\end{aligned}
$$

Komponen varans famili $\left(\sigma_{f}^{2}\right)$ diasumsikan sebesar $1 / 3$ varians genetik aditif $\left(\sigma^{2} \mathrm{~A}\right)$, karena benih dikumpulkan dari pohon induk dengan penyerbukan alami pada hutan alam dimana sebagian benih kemungkinan hasil dari kawin kerabat (neighborhood inbreeding)

\section{Keterangan:}

$\mathrm{h}^{2}{ }_{\mathrm{f}} \quad=$ nilai heritabilitas famili

$\mathrm{h}^{2}{ }_{\mathrm{i}} \quad=$ nilai heritabilitas individu

$\sigma^{2} \quad=$ komponens varians famili

$\sigma^{2}{ }_{b f} \quad=$ komponens varians interaksi antara blok dan famili

$\sigma_{\mathrm{e}}^{2} \quad=$ komponens varians error

$\mathrm{n} \quad=$ rerata harmonik jumlah pohon per plot

$\mathrm{b}=$ rerata harmonik jumlah blok

Korelasi genetik $\left(\mathrm{r}_{\mathrm{g}}\right)$ dihitung menurut metodologi dari Williams and Matheson (1994) yang didasarkan rumus sebagai berikut:

$$
r_{g}=\frac{\operatorname{Cov}_{f}(X, Y)}{\left[\sigma_{f}^{2}(x) \cdot \sigma_{f}^{2}(y)\right]^{1 / 2}}
$$

Keterangan:

$\operatorname{Cov}_{\mathrm{f}}(\mathrm{X}, \mathrm{Y})=$ kovarian dua sifat $(\mathrm{x}$ dan $\mathrm{y})$ pada level famili

$\sigma_{\mathrm{f}}^{2}(\mathrm{x})=$ varian sifat $(\mathrm{x})$ pada level famili

$\sigma_{\mathrm{f}}^{2}(\mathrm{y})=$ varian sifat $(\mathrm{y})$ pada level famili

Pada setiap plot dilakukan pengamatan gejala penyakit dan intensitas penyakit. Persentase luas serangan penyakit dan intensitas penyakit pada setiap plot pengamatan dihitung dengan rumus (Rahayu $d k k ., 1999)$ sebagai berikut: 


$$
\begin{gathered}
\text { Luas serangan }(\mathrm{LS})=(\mathrm{n} / \mathrm{N}) \times 100 \% \\
\text { Intensitas serangan }=((\mathrm{n} 0 \times \mathrm{z} 0+(\mathrm{n} 1 \times \mathrm{z} 1)+\ldots .+(\mathrm{n} 5 \times \mathrm{z} 5)) /(\mathrm{N} \times \mathrm{Z}) \times 100 \%
\end{gathered}
$$

\section{Dimana :}

$\begin{aligned} \mathrm{n} & \text { jumlah pohon yang } \\ & \text { terinfeksi } \\ \mathrm{n} 0, \mathrm{n} 1, \mathrm{n} 2, \mathrm{n} 3, \mathrm{nx}= & \text { jumlah pohon dengan } \\ & \text { indeks skor } 1,2,3 \ldots \mathrm{x} \\ \mathrm{z} 0, \mathrm{z} 1, \mathrm{z} 2, \mathrm{z} 3, \mathrm{zx}= & \text { skor penyakit karat } \\ & \text { tumor dengan indeks } \\ & \text { skor } 1,2,3 \ldots \mathrm{x} \\ = & \text { jumlah total pohon } \\ \mathrm{N} & \text { dalam satu plot } \\ \mathrm{Z} & \text { skor tertinggi }\end{aligned}$

\section{HASIL DAN PEMBAHASAN}

\section{A. Pertumbuhan Tanaman}

Persen hidup merupakan indikasi kemampuan tumbuh dan adaptasi tanaman terhadap kondisi lingkugan tempat tumbuhnya pada lahan yang memiliki perbedaan dengan tempat asalnya. Hasil analisis data uji keturunan sengon umur 6 dan 12 bulan di Bondowoso, Jawa Timur ditunjukkan pada Tabel 4.

Dari Tabel 4, dapat diketahui bahwa rata-rata persen hidup tanaman umur 6 bulan sebesar 98,5\% dengan kisaran 96\% - 100\%, sedangkan rata-rata persen hidup tanaman umur 12 bulan sebesar 96,9\% dengan kisaran 88\% - 99\%. Pada umur 6 bulan rata-rata tinggi pohon adalah sebesar $2,5 \mathrm{~m}$, rata-rata tinggi tanaman sengon tertinggi mencapai 2,6 m (Solomon) dan terendah 2,3 cm (Kurulu), untuk rata-rata diameter batang sebesar $2,7 \mathrm{~cm}$, rata-rata diameter terbesar 3,4 cm (Hobikosi) dan terendah 2,7 $\mathrm{cm}$ (Elagaima).

Tabel 4. Rata-rata persen hidup, tinggi dan diameter tanaman pada uji keturunan sengon umur 6 dan 12 bulan di Bondowoso, Jawa Timur

\begin{tabular}{lcccccc}
\hline \multirow{3}{*}{ Provenan } & \multicolumn{3}{c}{ Umur 6 bulan } & \multicolumn{3}{c}{ Umur 12 bulan } \\
\cline { 2 - 7 } & $\begin{array}{c}\text { Persen } \\
\text { hidup }(\%)\end{array}$ & Tinggi $(\mathrm{m})$ & $\begin{array}{c}\text { Diameter } \\
(\mathrm{cm})\end{array}$ & $\begin{array}{c}\text { Persen hidup } \\
(\%)\end{array}$ & Tinggi $(\mathrm{m})$ & $\begin{array}{c}\text { Diameter } \\
(\mathrm{cm})\end{array}$ \\
\hline Holima & 99 & 2,6 & 3,1 & 99 & 5,5 & $\mathbf{6 , 3}$ \\
Meagama & $\mathbf{1 0 0}$ & 2,6 & 3,3 & $\mathbf{9 9}$ & $\mathbf{5 , 6}$ & 6,2 \\
Elagaima & 97 & 2,4 & $\mathbf{2 , 7}$ & 95 & 5,0 & 5,6 \\
Kurulu & 99 & $\mathbf{2 , 3}$ & 2,9 & 98 & 5,0 & 5,4 \\
Wadabi & 98 & 2,4 & 2,8 & 96 & 5,0 & 5,04 \\
Nifasi & 99 & 2,4 & 2,8 & 99 & 4,9 & $\mathbf{4 , 8 4}$ \\
Worbag & 98 & 2,4 & 2,8 & 98 & $\mathbf{4 , 8}$ & 5,1 \\
Maidi & 99 & 2,5 & 3,0 & 98 & 5,2 & 5,5 \\
Hobikosi & 100 & 2,6 & $\mathbf{3 , 4}$ & 99 & 5,2 & 6,0 \\
Solomon & $\mathbf{9 6}$ & $\mathbf{2 , 7}$ & 3,1 & $\mathbf{8 8}$ & 5,0 & 5,7 \\
Rata-rata & $\mathbf{9 8 , 5}$ & $\mathbf{2 , 5}$ & $\mathbf{2 , 9}$ & $\mathbf{9 6 , 9}$ & $\mathbf{5 , 1}$ & $\mathbf{5 , 6}$ \\
\hline
\end{tabular}


Pada umur 12 bulan rata-rata tinggi pohon adalah sebesar $5,1 \mathrm{~m}$, rata-rata tinggi tanaman sengon tertinggi mencapai 5,6 m (Meagama), dan terendah 4,8 m (Worbag), untuk rata-rata diameter batang sebesar $5,6 \mathrm{~cm}$, rata-rata diameter terbesar $6,3 \mathrm{~cm}$ (Holima) dan terendah 4,8 (Nifasi). Respon pertumbuhan yang baik ini diduga karena selain faktor genetik, kondisi geografis dan lingkungan sangat mendukung di mana kondisi lahan plot sengon tersebut berada pada ketinggian $800 \mathrm{~m}$ dpl, dan tidak berbeda jauh dengan kondisi tempat asal pengumpulan sumber benih. Selain itu pada plot uji tersebut, pemeliharaan berupa pemupukan, dan pembersihan gulma dilakukan secara periodik setiap 6 bulan sekali, sehingga memberikan respon pertumbuhan yang baik.

\section{B. Analisis Varians}

Data pengukuran tinggi dan diameter memberikan informasi lebih lanjut bahwa terdapat variasi pertumbuhan, baik di antara ke sepuluh provenans maupun di antara famili dalam provenans yang diuji (Tabel 5).

Tabel 5. Analisis sidik ragam tinggi dan diameter tanaman pada uji keturunan sengon umur 6 dan 12 bulan di Bondowoso, Jawa Timur

\begin{tabular}{|c|c|c|c|c|c|c|}
\hline SV & $\mathrm{db}$ & RK & Nilai F & $\mathrm{db}$ & RK & Nilai F \\
\hline & \multicolumn{3}{|c|}{ Tinggi (6 bln) } & \multicolumn{3}{|c|}{ Tinggi (12 bln) } \\
\hline Blok & 3 & 0,40 & $1,05^{\mathrm{ns}}$ & 3 & 6,05 & $6,20 * *$ \\
\hline Baris (Blok) & 24 & 0,95 & $2,47 * *$ & 24 & 2,91 & $2,99 * *$ \\
\hline Kolom (Blok) & 36 & 1,33 & $3,43 * *$ & 36 & 11,39 & $11,68 * *$ \\
\hline Provenans & 9 & 1,29 & $1,50^{\mathrm{ns}}$ & 9 & 1,91 & $1,19^{\text {ns }}$ \\
\hline Fam(Prov) & 61 & 0,86 & $1,62 * *$ & 61 & 1,60 & $1,02^{\mathrm{ns}}$ \\
\hline Blok*Fam(Prov) & 146 & 0,53 & $1,40 * *$ & 146 & 1,56 & $1,48 * *$ \\
\hline \multirow[t]{2}{*}{ Error } & 824 & 0,38 & & 807 & 0,97 & \\
\hline & \multicolumn{3}{|c|}{ Diameter (6 bln) } & \multicolumn{3}{|c|}{ Diameter (12 bln) } \\
\hline Blok & 3 & 1,04 & $1,45^{\mathrm{ns}}$ & 3 & 17,39 & $8,73^{* *}$ \\
\hline Baris (Blok) & 24 & 2,07 & $2,89 * *$ & 24 & 5,54 & $2,78 * *$ \\
\hline Kolom (Blok) & 36 & 2,08 & $3,78 * *$ & 36 & 11,42 & $5,73^{* *}$ \\
\hline Provenans & 9 & 1,49 & $1,03^{\mathrm{ns}}$ & 9 & 10,89 & $3,84 * *$ \\
\hline Fam(Prov) & 61 & 1,45 & $1,19^{\mathrm{ns}}$ & 61 & 2,82 & $1,30^{\text {ns }}$ \\
\hline Blok*Fam(Prov) & 146 & 1,21 & $1,69 * *$ & 146 & 2,18 & $1,09^{\text {ns }}$ \\
\hline Error & 824 & 0,71 & & 807 & 1,99 & \\
\hline
\end{tabular}

Ket: **) berbeda nyata pada taraf uji $1 \%(\mathrm{P}<0,01)$ ns $)$ berbeda tidak nyata pada taraf uji $5 \%(\mathrm{P}<0,05)$ 
Hasil analisis varians menunjukkan bahwa tidak terdapat perbedaan yang nyata antara provenans uji untuk tinggi pohon dan diameter batang tanaman sengon umur 6 bulan. Variasi pertumbuhan tinggi juga tidak ditunjukkan antar provenans pada umur 12 bulan, sedangkan pada diameter batang menunjukkan perbedaan yang nyata antar provenans yang diuji (Tabel 5). Baris dalam blok, dan kolom dalam blok pada umur 6 dan 12 bulan menyebabkan keragaman pada sifat pertumbuhan tinggi dan diameter, hal ini menunjukkan bahwa di dalam blok tersebut terdapat perbedaan lingkungan tempat tumbuh searah baris dan kolom. Hal tersebut menunjukkan bahwa rancangan blok tidak lengkap meningkatkan presisi dari penelitian, karena baris dan kolom di dalam blok terdapat heteroginitas tanah.

\section{Nilai heritabilitas dan korelasi genetik}

Keragaman fenotipe berasal dari susunan genetik yang diturunkan dan karena adanya faktor lingkungan tempat tumbuh tanaman uji. Untuk melihat proporsi yang mengendalikan sifat yang diukur (tinggi dan diameter) dan hubungan keeratan dari kedua sifat tersebut, dilakukan perhitungan nilai heritabilitas dan korelasi genetik. Taksiran kedua nilai tersebut sangat bermanfaat dalam melakukan seleksi dan menaksir besarnya peningkatan genetik yang dihasilkan (Hardiyanto, 2007).

Pendugaan nilai heritabilitas individu $\left(\mathrm{h}_{\mathrm{i}}^{2}\right)$ untuk tinggi tanaman sengon umur 6 dan 12 bulan termasuk katagori rendah $(0,07$ dan 0,08$)$ dan untuk diameter batang termasuk katagori sedang $(0,11$ dan 0,27) (Cotteril dan Dean, 1990). Hal ini berarti untuk tinggi pohon faktor lingkungan lebih dominan mempengaruhi pertumbuhannya, sedangkan untuk sifat diameter ada pengaruh yang seimbang antara faktor genetik dan faktor lingkungan dalam mempengaruhi pertumbuhannya. Demikian juga nilai heritabilitas famili untuk tinggi pohon umur $6 \quad\left(\mathrm{~h}_{\mathrm{f}}^{2}=0,16\right)$ dan 12 bulan $\left(\mathrm{h}_{\mathrm{f}}^{2}=0,15\right)$ termasuk katagori rendah, sementara itu untuk diameter termasuk katagori rendah sampai sedang $(0,21$ dan 0,43$)$. Nilai heritabilitas sifat-sifat pohon kemungkinan bisa berubah sejalan dengan penambahan umur pohon (Na'iem $d k k$., 2005). Hal tersebut disebutkan juga oleh Ofori et al., (2001) yang melakukan penelitian terhadap jenis Milicia exelsa (Iroko) pada umur 4 dan 12 bulan di Mesewan, Ghana. Hasilnya menunjukkan 
bahwa nilai heritabilitas bertambah seiring bertambahnya umur tanaman, pada umur 4 bulan nilai heritabilitas 0,01 dan setelah umur 12 bulan naik menjadi 0,2. Namun demikian, secara umum pada sengon nilai heritabilitas untuk pertumbuhan tinggi dan diameter pohon sampai umur 12 bulan dalam kisaran rendah sampai sedang, sebagaimana dilaporkan dari hasil penelitian di beberapa lokasi yang disajikan pada Tabel 6 .

Tabel 6. Heritabilitas individu dan famili untuk sifat tinggi dan diameter batang pada uji keturunan sengon di beberapa lokasi

\begin{tabular}{|c|c|c|c|c|c|c|}
\hline \multirow[t]{2}{*}{ Lokasi } & \multirow{2}{*}{$\begin{array}{l}\text { Umur } \\
\text { Tanaman }\end{array}$} & \multicolumn{2}{|c|}{$\begin{array}{l}\text { Heritabilitas } \\
\text { Individu }\end{array}$} & \multicolumn{2}{|c|}{$\begin{array}{l}\text { Heritabilitas } \\
\text { famili }\end{array}$} & \multirow[t]{2}{*}{ Pustaka } \\
\hline & & Tinggi & Diameter & Tinggi & Diameter & \\
\hline $\begin{array}{l}\text { Cikampek (Jawa } \\
\text { Barat) }\end{array}$ & 4 bln & 0,16 & 0,10 & & & Hadiyan, Y (2009) \\
\hline $\begin{array}{l}\text { Candiroto (Jawa } \\
\text { Tengah) }\end{array}$ & 4 bln & & & 0,75 & & Susanto, M (1997) \\
\hline $\begin{array}{l}\text { Cikabayan } \\
\text { (Bogor) }\end{array}$ & $6 \mathrm{bln}$ & 0,14 & 0,05 & 0,31 & 0,14 & Mukmin, A (2004) \\
\hline \multirow[t]{2}{*}{$\begin{array}{l}\text { Kediri (Jawa } \\
\text { Timur) }\end{array}$} & 8 bln & & 0,16 & & 0,42 & $\begin{array}{l}\text { Ismail, B dan } \\
\text { Hadyan, Y (2008) }\end{array}$ \\
\hline & 24 bln & & 0.02 & & & $\begin{array}{l}\text { Baskorowati, dkk } \\
\text { (2012) }\end{array}$ \\
\hline $\begin{array}{l}\text { Candiroto (Jawa } \\
\text { Tengah) }\end{array}$ & 3 thn & & & 0,78 & 0,68 & Susanto, M (1999) \\
\hline Arid (India) & 3 thn & 0,24 & 0,20 & & & $\begin{array}{l}\text { O.P. Toky, N. R.P. } \\
\text { Bisht (1995) }\end{array}$ \\
\hline
\end{tabular}

Untuk melihat keeratan hubungan (korelasi genetik) diantara dua sifat pertumbuhan tanaman sengon pada uji keturunan di Bondowoso, Jawa Timur umur 6 dan 12 bulan maka dilakukan perhitungan korelasi antar sifat. Nilai korelasi genetik antara tinggi dan diameter memiliki nilai positif dan cukup tinggi $(0,88$ dan 0,85). Mukmin (2004) melaporkan pada uji keturunan sengon umur 6 bulan di Cikabayan (Bogor, Jawa Barat) nilai korelasi genetik antara kedua sifat yang diukur juga memberikan nilai positif dan tinggi sebesar $(0,83)$. Penelitian lain yang dilaporkan Ismail dan Hadiyan (2008) pada penelitian uji keturunan sengon di Kediri (Jawa Timur) umur 8 bulan menunjukkan korelasi tinggi dan diameter memiliki nilai positif $(0,89)$. Demikian juga pada uji keturunan sengon di Candiroto umur 3 tahun, korelasi genetik antara sifat tinggi dan diameter sangat kuat sebesar 0,96 (Susanto, 1999). Nilai 
korelasi genetik ini dapat menunjukkan derajat perubahan suatu sifat sebagai akibat perubahan sifat yang lain. Dengan korelasi genetik yang tinggi, maka peningkatan diameter pohon akan selalu diikuti dengan peningkatan tinggi pohon atau sebaliknya.

\section{Ketahanan terhadap Penyakit Karat Tumor}

Hasil pengamatan di lapangan untuk luas serangan dan intensitas serangan penyakit karat tumor pada umur 6 dan 12 bulan disajikan pada dan Gambar 1 berikut ini.

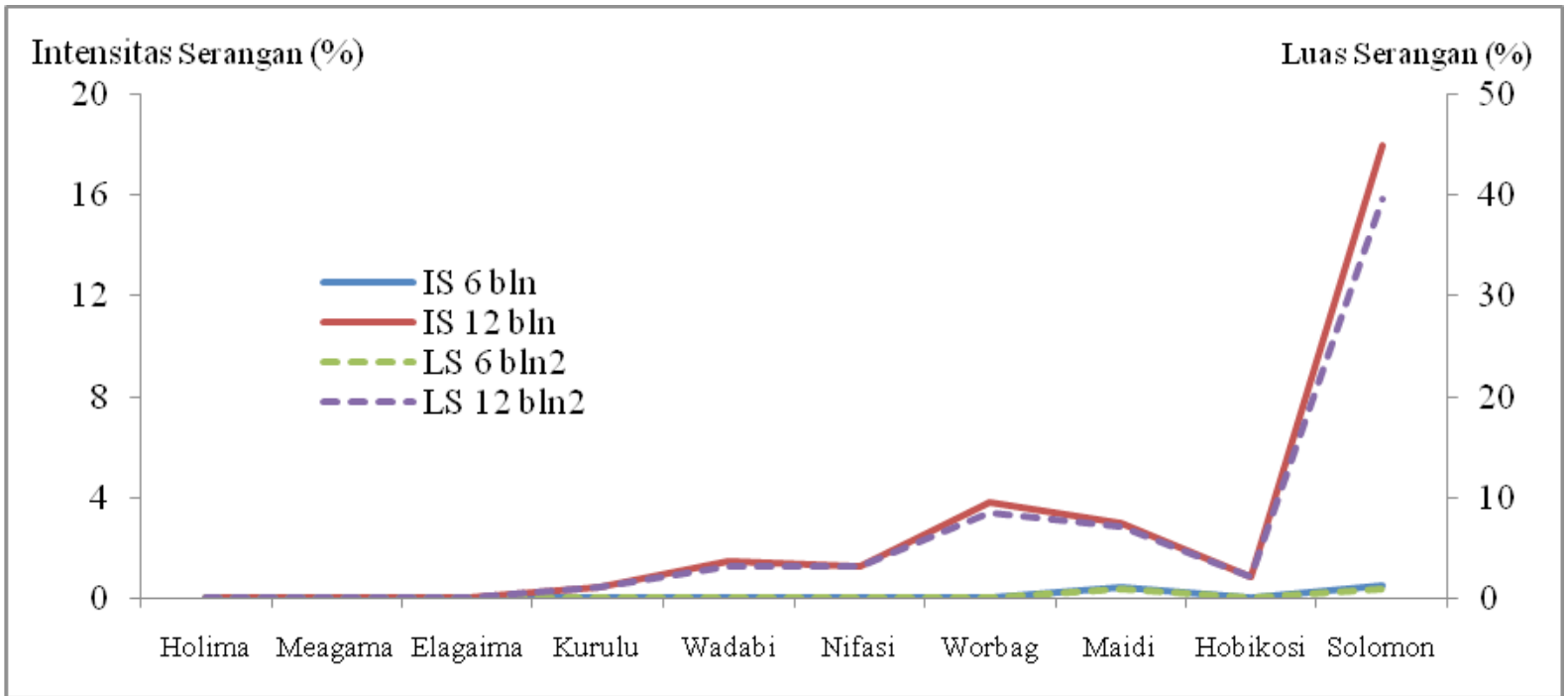

Gambar 1. Rerata luas serangan (LS dalam \%) dan intensitas serangan (IS dalam \%) penyakit karat tumor pada uji keturunan sengon umur 6 dan 12 bulan di Bondowoso, Jawa Timur

Dari Gambar 1, dapat dilihat bahwa rerata serangan penyakit karat tumor terbesar ditunjukkan pada provenans Solomon sebesar $0,85 \%$, dengan intensitas serangan 0,51\%, diikuti provenans Maidi dengan luas serangan sebesar $0,78 \%$ dan intensitas serangan sebesar $0,47 \%$. Pada umur 12 bulan, luas serangan dan intensitas serangan terbesar dicapai provenans Solomon dengan luas serangan sebesar $39,65 \%$ dan intensitas serangan sebesar $17,99 \%$, diikuti provenans Worbag dengan luas serangan $8,47 \%$ dan intensitas serangan 3,80\%, provenans Maidi dengan luas serangan 7,08\% dan intensitas serangan sebesar $2,99 \%$.

Dari Gambar 1, terlihat jelas bahwa luas serangan dan intensitas serangan pada plot uji keturunan sengon di Bondowoso, Jawa Timur meningkat sejalan dengan bertambahnya umur tanaman. Selain itu 
pada tanaman muda (6 bulan), serangan umumnya masih terjadi pada pucuk tanaman belum sampai menyerang bagian batang maupun cabang, tetapi pada umur 1 tahun menurut hasil pengamatan di lapangan banyak ditemukan karat tumor yang sudah menyerang bagian batang, cabang maupun ranting.

Dari hasil pengamatan di lapangan pada uji keturunan sengon umur 6 bulan, provenans-provenans dengan persentase luas serangan dan intensitas serangan $0 \%$ atau tidak diserang sama sekali ditunjukkan oleh provenans Holima, Meagama, Elagaima, Kurulu, Wadabi, Nifasi dan Worbag. Sementara itu luas serangan dan intensitas serangan $0 \%$ atau tidak diserang sama sekali sampai umur 12 bulan ditunjukkan provenans Holima, Meagama dan Elagaima (Gambar 1). Penelitian sebelumnya pada tingkat persemaian menunjukkan bahwa provenans dari Wamena menunjukkan lebih toleran terhadap serangan jamur karat tumor dengan luas serangan dan intensitas serangan sebesar $0 \%$, dibandingkan dengan provenans dari Jawa yang mempunyai luas serangan berkisar $86,1-94,4 \%$ dan intensitas serangan 53-60\% (Baskorowati dan Nurrohmah, 2011).
Sejauh ini upaya pengendalian penyakit karat tumor sudah dilakukan antara lain dengan pendekatan silvikultur dan berbagai fungisida (Anggraeni, 2009). Upaya penanggulangan serangan hama dan penyakit pada sengon dapat diatasi dengan mengintroduksi sumber genetik baru di luar populasi yang telah ada sehingga diharapkan keragaman genetik sengon dapat ditingkatkan. Introduksi sumber genetik baru juga dapat digunakan untuk menguji resistensi terhadap hama dan penyakit. Inisiasi pendekatan secara genetis yaitu dengan perluasan basis genetik tanaman sengon telah dilakukan dengan penanaman uji keturunan sengon yang materi genetiknya berasal dari 9 provenans asal Papua dan 1 provenans asal Solomon. Pengukuran presentase kejadian penyakit (luas serangan penyakit) dan intensitas serangan penyakit karat tumor pada sengon dilakukan untuk mengukur perkembangan epidemik dan mengetahui faktor-faktor yang mempengaruhi perkembangan penyakit. Semangun (1996) menyebutkan bahwa penyakit epidemik adalah meningkatnya penyakit dengan hebat pada waktu dan wilayah tertentu dalam suatu populasi tumbuhan. 


\section{KESIMPULAN}

Dari evaluasi awal uji keturunan sengon terhadap ketahanan serangan penyakit umur 6 sampai 12 bulan dapat ditarik kesimpulan sebagai berikut:

1. Persentase tumbuh dari provenansprovenans yang diuji umur 6 bulan sebesar 98,5\% dengan kisaran 96\% - $100 \%$ dan rata-rata persen hidup tanaman umur 12 bulan sebesar 96,9\% dengan kisaran $88 \%-99 \%$.

2. Pada umur 6 bulan provenans dari Solomon menunjukkan pertumbuhan tinggi terbaik, dan diameter terbaik ditunjukkan oleh provenans Hobikosi. Pada umur 12 bulan pertumbuhan terbaik ditunjukkan provenans Meagama, dan diameter terbaik provenans Holima.

3. Nilai heritabilitas individu dan famili untuk tinggi tanaman sengon umur 6 dan 12 bulan termasuk katagori rendah $\left(\mathrm{h}^{2}=\right.$ $\left.0,07-0,08, \mathrm{~h}_{\mathrm{f}}^{2}=0,16-0,15\right)$, dan untuk diameter termasuk katagori sedang, rendah sampai sedang $\left(\mathrm{h}^{2}=0,011-0,27\right.$, $\left.\mathrm{h}_{\mathrm{f}}^{2}=0,21-0,43\right)$, nilai korelasi genetik antara tinggi dan diameter memiliki nilai positif dan cukup tinggi $(0,88$ dan 0,85$)$.

4. Provenans dengan persentase luas serangan dan intensitas serangannya 0
$\%$ (tahan terhadap serangan penyakit karat tumor sampai umur 12 bulan) adalah provenans Holima, Meagama dan Elagaima.

\section{UCAPAN TERIMA KASIH}

Penulis mengucapkan terima kasih yang tidak terhingga kepada Dr. Liliana Baskorowati, S.Hut, MP sebagai koordinator penelitian sengon, kepada peneliti dan teknisi team penelitian sengon dan temanteman di KHDTK Bondowoso, Jawa Timur yang telah membantu dalam pembangunan uji keturunan sengon, serta pelaksanaan pengamatan dan pengukuran di lapangan yang tidak dapat disebutkan satu persatu.

\section{DAFTAR PUSTAKA}

Anggraeni, I. 2009. Penyakit Karat Tumor Pada Sengon (Paraserianthes falcataria (L) Nielsen) Di Perkebunan Glemore Banyuwangi, Jawa Timur. Jurnal Penelitian Hutan Tanaman. Vol. 6 No. 5, November 2009, 311-321.

Anggraeni, I., Dendang, B., Lelana, L.E., 2010. Pengendalian Penyakit Karat Tumor (Uromycladium tepperianum (Saacc.) Mc. Alpin) Pada Sengon (Falcataria moluccana (Miq.) Barneby\&J.W. Grimes) Di Panjalu Kabupaten Ciamis Jawa Barat. Jurnal Penelitian Hutan Tanaman. Vol.7 No. 5, Desember 2010. 273-278.

Baskorowati, L., Nurrohmah S. H. 2011. Variasi Ketahanan Terhadap Penyakit Karat Tumor pada Sengon Tingkat Semai. Jurnal Pemuliaan Tanaman Hutan, Vol.5 No.3,November 2011. Hal 129138. Balai Penelitian Bioteknologi dan PemuliaanTanaman Hutan. Yogyakarta. 
No. ISSN 1693-7147 No Akreditasi: 162/ AkredLIPI/P2MBI/07/2009

Baskorowati, L., Susanto, M., Charomaeni, M. 2012. Genetic variability in resistance of Falcataria moluccana (Miq.) Barneby \& J.W. Grimes to gall rust disesase. Journal of Forestry Research Vol 9, No 1. Hal 1-9.

Cotteril, P.P and C.A Dean. 1990. Succesful Tree Breeding with Index Selection. CSIRO Devision of Forestry and forest Product. Australia

Gusdwiyanti, F. 2009. Keragaman sengon Solomon (Paraserianthes Falcataria L. Nielsen) Pada Uji Keturunan di Hutan Percobaan Cirangsad, Bogor, Jawa Barat (Skripsi). Departemen Manajemen Hutan Fakultas Kehutanan Institut Pertanian Bogor (tidak diterbitkan)

Hadiyan, Y. 2010. Evaluasi Pertumbuhan Awal Kebun Benih Semai Uji Keturunan Sengon (Falcataria moluccana sinonim: Paraserianthes falcataria) Umur 4 Bulan di Cikampek, Jawa Barat. Jurnal Penelitian Hutan Tanaman Vol. 7 No.2, (85-91). Balai Penelitian Bioteknologi dan Pemuliaan Tanaman Hutan Yogyakarta

Hardiyanto, E.B., 2007. Hand Out Mata Kuliah Pemuliaan Pohon, Program Pasca Sarjana Fakultas Kehutanan, Universias Gadjah Mada, Yogyakarta.

Ismail, B. dan Hadiyan, Y. 2010. Evaluasi Awal Uji Keturunan Sengon (Falcataria moluccana) Umur 8 Bulan di Kabupaten Kediri, Jawa Timur. Jurnal Penelitian Hutan Tanaman Vol. 2 No.3, (287-293). Balai Penelitian Bioteknologi dan Pemuliaan Tanaman Hutan Yogyakarta

Leksono, B. 1998. Analisis Kombinasi Provenan dan Ras Lahan Sengon (Paraserianthes Falcataria) Umur 6 Bulan di Muara Teweh, Kalimantan Tengah. Bulletin Kehutanan No. 36. Balai Teknologi Reboisasi Palembang

Martawijaya, Abdurahim, Iding Kartasujana, Kosasih Kadir dan Soewanda Amongprawira. 1992. Indonesia Wood Atlas Vol. 2 Dept.of For. AFRD. For. Prod. Res. and Dev. Center. Bogor. Indonesia

Mukmin, A (2004). Uji Keturunan Saudara (Paraserianthes Falcataria L. Nielsen) Di Taman Hutan Blok Cikabayan (Skripsi). Departemen Manajemen Hutan Fakultas Kehutanan Institut Pertanian Bogor (tidak diterbitkan)

Na'iem, 2005. Pemuliaan Pohon dan Hutan Tanaman Prospektif di Indonsia. Seminar Nasional. Peran Konservasi Sumber Daya Genetik, Pemuliaan dan Silvikultur dalam Mendukung Rehabilitasi Hutan.
Yogyakarta, 26-27 Mei 2005

Ofori, D.A., Cobbinah, J.R. dan Appiah-Kwarteng. 2002. Genetic Variation, Heritability and Expected Genetic Gain in Milicia exelsa (Iroko) Journal of Forest Tropical Science vol 13 (2): 344-351

Rahayu, S., M. Na'iem, Hardiwinoto, S. 1999. Potensi Hama dan Penyakit pada Gmelina arborea Roxb: Studi Kasus di PT Surya Hutan Jaya (Kaltim). Dalam Prosiding Seminar Nasional Status Silvikultur 1999 (p 121-125). Peluang dan Tantangan menuju Produktivitas dan Kelestarian Sumberdaya Hutan Jangka Panjang. Diterbitkan pada tahun 200. Fakultas Kehutanan Universitas Gadjah Mada, Yogyakarta

Semangun, H. 1996. Pengantar Penyakit Tumbuhan. Gadjah Mada University Press. Yogyakarta

Toky, O.P., Kumar, N., Bisht, R.P. 1996. Variation in Grow of 3 Year Provenance Trial of Albizia lebbek (L.) Benth. In Arid India. Silvae Genetica 45, 1 (31-33)

Siregar, U.J. dan Saimima, P.A., 2011. Studi AlfaAmylase Inhibitor Pada Pohon Sengon (Paraserianthes falcataria (L) Nielsen) Provenan Kediri, Solomon dan Subang. Jurnal Silvikultur Tropika. Vol.2 No. 01 April 2011, Hal. 52-58.

Turnbull, J.W. 1996. Influence of Collection activities on Forest Tree Seed Quality in Yapa, A. C., ed. 1996. Intl. Symp. Recent Advances in Tropical Tree Seed Technology and Planting Stock Production. ASEAN Forest Tree Seed Centre Project. Muaklek, Saraburi, Thailand

Williams, E.R. and A.C. Matheson. 1994. Experimental Design and Analysis for Use in Tree Improvement. CSIRO Information Service. Victoria, Australia

Zobel, B. and Talbert J., 1984. Applied Tree Improvement. John Wiley and Sons, Inc. Canada 